\title{
Synthesis, structure and properties of $\mathbf{N}$-R-amides and hydrazides of 2-[4-R-5-(theophylline-7'-yl)-1,2,4-triazole-3-ylthio]acetic acid
}

\author{
Zaporizhzhia State Medical University, Ukraine
}

One of the most important tasks of modern pharmaceutical science is the search for new biologically active substances, which have high efficacy and low toxicity. Derivatives of 1,2,4-triazole and theophylline are a promising class of compounds for synthesis of biologically active substances on their basis, due to a wide range of biological activity of these heterocycles' derivatives.

The purpose of work is the development of efficient methods for synthesis of new amides and hydrazides of 2-[4-R-5-(theophylline7'-yl)-1,2,4-triazole-3-ylthio]acetic acid $\left(\mathrm{R}=\mathrm{CH}_{3}, \mathrm{C}_{2} \mathrm{H}_{5}, \mathrm{C}_{6} \mathrm{H}_{5}\right)$ with variation of the reactions conditions and the study of physical properties of the obtained compounds.

Materials and methods. As a key source of reagents we used 7'-((3-thio-4-R-4H-1,2,4-triazole-5-yl)methyl)theophylline and esters of 2-[4-R-5-(theophylline-7'-yl)-1,2,4-triazole-3-ylthio]acetic acid, which were obtained by known methods from readily available raw materials. By heating in ethanol medium the corresponding amines (ammonia, methylamine, ethylamine, monoethanolamine, diethanolamine), $n$-propyl ether 2-[4-R-5-(theophylline-7'-yl)-1,2,4-triazole-3-ylthio]acetic acid a series of amides of 2-[4-R-5(theophylline-7'-yl)-1,2,4-triazole-3-ylthio]acetic acid were obtained. Hydrazide of 2-[4-R-5-(theophylline-7'-yl)-1,2,4-triazole-3ylthio]acetic acid was synthesized by interaction of corresponding esters of 2-[4-R-5-(theophylline-7'-yl)-1,2,4-triazole-3-ylthio]acetic acid with an aqueous solution of hydrazine hydrate in ethanol medium. The structure of the obtained compounds is confirmed by data of elemental analysis, ${ }^{1} \mathrm{H}$ NMR spectroscopy and IR-spectrophotometry. The individuality of substances is established by using high performance liquid chromatography with diode-array and mass spectrometric detection.

Results. Optimal methods of obtaining amides and hydrazides of 2-[4-R-5-(theophylline-7'-yl)-1,2,4-triazole-3-ylthio]acetic acid have been developed. Getting investigated amides by two alternative ways of synthesis, it was established that the initial interaction of thiol with 2-chloracetamide proceeds with high yield product of the reaction compared to the reaction between a corresponding ester with ammonia.

Conclusions. 15 amide and 3 hydrazide 2-[4-R-5-(theophylline-7'-yl)-1,2,4-triazole-3-ylthio]acetic acids have been synthesized, their structure has been established and physical properties have been studied.

Key words: theophylline, 1,2,4-triazole, amides, hydrazide, synthesis, physical properties.

Current issues in pharmacy and medicine: science and practice 2017; 10 (3), 254-258

Синтез, будова та властивості $N$-R-амідів і гідразидів 2-[4-R-5-(теофілін-7'-іл)-1,2,4-тріазол-3-ілтіо]ацетатної кислоти

\section{А. С. Гоиуля}

Одним із найважливіших завдань сучасної фармацевтичної науки є пошук нових біологічно активних речовин, які володіли б високою ефективністю та низькою токсичністю. Похідні 1,2,4-тріазолу та теофіліну є перспективним класом хімічних сполук для синтезу на їхній основі біологічно активних речовин, що зумовлено широким спектром біологічної активності похідних цих гетероциклів.

Мета роботи - розроблення ефективних методів синтезу нових амідів і гідразидів 2-[4-R-5-(теофілін-7'-іл)-1,2,4-тріазол-3-ілтіо]ацетатної кислоти $\left(\mathrm{R}=\mathrm{CH}_{3}, \mathrm{C}_{2} \mathrm{H}_{5}, \mathrm{C}_{6} \mathrm{H}_{5}\right)$ і дослідження фізичних властивостей сполук, що отримали.

Матеріали та методи. Як ключові вихідні реагенти використали 7'-((3-тіо-4-R-4H-1,2,4-тріазол-5-іл)метил)теофілін та ефіри 2-[4-R-5-(теофілін-7'-іл)-1,2,4-тріазол-3-ілтіо]ацетатної кислоти, котрі отримали за відомими методиками з доступної сировини. Нагріванням в етанолі відповідних амінів (амоніак, метиламін, етиламін, моноетаноламін, діетаноламін) із $н$-пропіловим ефіром 2-[4-R-5-(теофілін-7'-іл)-1,2,4-тріазол-3-ілтіо]ацетатної кислоти отримали ряд амідів 2-[4-R-5-(теофілін-7'-іл)-1,2,4-тріазол3-ілтіо]ацетатної кислоти. Взаємодією 7'-((3-тіо-4-R-4H-1,2,4-тріазол-5-іл)метил)теофіліну з 2-хлорацетамідом у присутності $\mathrm{NaOH}$ із високими виходами отримані відповідні аміди. Гідразиди 2-[4-R-5-(теофілін-7'-іл)-1,2,4-тріазол-3-ілтіо]ацетатної кислоти синтезовані взаємодією відповідних ефірів 2-[4-R-5-(теофілін-7'-іл)-1,2,4-тріазол-3-ілтіо]ацетатної кислоти 3 водним розчином гідразин гідрату в середовищі етанолу. Структура сполук, котрі одержали, підтверджена даними елементного аналізу, ${ }^{1} \mathrm{H}$ ЯМР-спектроскопії та ІЧ-спектрофотометрії. Індивідуальність речовин встановлена за допомогою високоефективної рідинної хроматографії з діодно-матричною та мас-спектрометричною детекцією.

Результати. Розроблені оптимальні методи отримання амідів і гідразидів 2-[4-R-5-(теофілін-7'-іл)-1,2,4-тріазол-3-ілтіо]ацетатної кислоти. Досліджено отримання амідів за двома альтернативними шляхами синтезу з використанням вихідного тіолу та отриманого на його основі складного ефіру: встановили, що взаємодія вихідного тіолу з 2-хлорацетамідом перебігає з більшим виходом продукту реакції порівняно з реакцією взаємодії відповідного ефіру з амоніаком.

Висновки. Синтезовано 15 амідів і 3 гідразиди 2-[4-R-5-(теофілін-7'-іл)-1,2,4-тріазол-3-ілтіо]ацетатної кислоти, встановлена їхн структура та вивчені фізичні властивості.

Ключові слова: теофілін, 1,2,4-тріазол, аміди, гідразиди, синтез, фізичні властивості.

Актуальні питання фармацевтичної і медичної науки та практики. - 2017. - Т. 10, № 3(25). - С. $254-258$ 


\section{Синтез, строение и свойства $N$-R-амидов 2-[4-R-5-(теофиллин-7'-ил)-1,2,4-триазол-3-илтио]ацетатной кислоты}

\section{А. С. Гоиуля}

Одной из важнейших задач современной фармацевтической науки является поиск новых биологически активных веществ, которые обладают высокой эффективностью и низкой токсичностью. Производные 1,2,4-триазола и теофиллина являются перспективным классом химических соединений для синтеза на их основе биологически активных веществ, что обусловлено широким спектром биологической активности производных этих гетероциклов.

Цель работы - разработка эффективных методов синтеза новых амидов и гидразидов 2-[4-R-5-(теофиллин-7'-ил)-1,2,4-триазол-3-илтио]ацетатной кислоты $\left(\mathrm{R}=\mathrm{CH}_{3}, \mathrm{C}_{2} \mathrm{H}_{5}, \mathrm{C}_{6} \mathrm{H}_{5}\right)$ и исследование физических свойств полученных соединений.

Материалы и методы. В качестве ключевых исходных реагентов использованы 7'-((3-тио-4-R-4H-1,2,4-триазол-5-ил)метил)теофиллин и эфиры 2-[4-R-5-(теофиллин-7'-ил)-1,2,4-триазол-3-илтио]ацетатной кислоты, которые были получены по известным методикам из доступного сырья. Нагреванием в этаноле соответствующих аминов (аммиак, метиламин, этиламин, моноэтаноламин, диэтаноламин) с $н$-пропиловым эфиром 2-[4-R-5-(теофиллин-7'-ил)-1,2,4-триазол-3-илтио]ацетатной кислоты получен ряд амидов 2-[4-R-5-(теофиллин-7'-ил)-1,2,4-триазол-3-илтио]ацетатной кислоты. Взаимодействием 7'-((3-тио4-R-4H-1,2,4-триазол-5-ил)метил)теофиллина с 2-хлорацетамидом в присутствии $\mathrm{NaOH}$ с высокими выходами получены соответствующие амиды. Гидразиды 2-[4-R-5-(теофиллин-7'-ил)-1,2,4-триазол-3-илтио]ацетатной кислоты синтезированы взаимодействием соответствующих эфиров 2-[4-R-5-(теофиллин-7'-ил)-1,2,4-триазол-3-илтио]ацетатной кислоты с водным раствором гидразин гидрата в среде этанола. Структура полученных соединений подтверждена данными элементного анализа, ${ }^{1}$ Н ЯМР-спектроскопии и ИК-спектрофотометрии. Индивидуальность веществ установлена с помощью высокоэффективной жидкостной хроматографии с диодно-матричной и масс-спектрометрической детекцией.

Результаты. Разработаны оптимальные методы получения амидов и гидразидов 2-[4-R-5-(теофиллин-7'-ил)-1,2,4-триазол-3-илтио]ацетатной кислоты. Исследовано получение амидов двумя альтернативными путями синтеза с использованием исходного тиола и полученного на его основе сложного эфира: установлено, что взаимодействие исходного тиола с 2-хлорацетамидом протекает с большим выходом продукта реакции в сравнении с реакцией взаимодействия соответствующего эфира с аммиаком.

Выводы. Синтезировано 15 амидов и 3 гидразида 2-[4-R-5-(теофиллин-7'-ил)-1,2,4-триазол-3-илтио]ацетатной кислоты, установлена их структура и изучены физические свойства.

Ключевые слова: теофиллин, 1,2,4-триазол, амиды, гидразиды, синтез, физические свойства.

Актуальные вопросы фармацевтической и медицинской науки и практики. - 2017. - Т. 10, № 3(25). - С. $254-258$

$\mathrm{O}$ ne of the important tasks of modern pharmaceutical science is the search for new biologically active substances that have high efficiency and low toxicity $[1,8,9]$. The derivatives of 1,2,4-triazole-3-thiol and theophylline are a very promising class of chemical compounds for the synthesis of biologically active compounds based on them, due to the wide spectrum of biological activity of these heterocycles' derivatives $[2-7,10]$. Objective reasons for the search for a number of 1,2,4-triazol-3-thiol and theophylline derivatives are the high synthetic and pharmacological potential of these synthones $[2,5,7,10]$. Our attention was drawn to previously unexplored amides and 2-[4-R-5-(theophylline-7'-yl)-1,2,4triazole-3-ylthio]acetic acid.

\section{The purpose of the work}

The purpose of the work is the synthesis of new amides and hydrazides of 2-[4-R-5-(theophylline-7'-yl)-1,2,4-triazol-3ylthio]acetic acid and the study of their physical properties.

\section{Materials and methods}

As the key starting reagents, we used 7'-((3-thio-4-R-4H1,2,4-triazol-5-yl)methyl)theophylline ester 2-[4-R-(theophylline-7'-yl)-1,2,4-triazol-3-ylthio]acetic acid, which were obtained by known methods from available raw materials. In the course of the research, it was found that by heating in ethanol, the corresponding amines (ammonia, methylamine, ethylamine, monoethanolamine, diethanolamine) from n-propyl ethers 2-[4-R-5-(theophyllin-7'-yl)-1,2,4-triazole3 -ylthio]acetic acid are formed to 2-[4-R-5-(theophyllin7'-yl)-1,2,4-triazol-3-ylthio]acetic acid amides. The solvent was evaporated, the residue crystallized. Interactions of 7'-((3-thio-4-R-4H-1,2,4-triazol-5-yl)methyl)theophylline with 2-chloroacetamide in the presence of $\mathrm{NaOH}$ in high yields yielded the corresponding amides (Fig. 1). Hydrazides 2-[4-R-5-(theophylline-7'-yl)-1,2,4-triazol-3-ylthio]acetic acid are synthesized by the interaction of the corresponding esters of 2-[4-R-5-(theophylline-7'-yl)-1,2,4-triazol-3-ylthio]acetic acid with an aqueous solution of hydrazine hydrate in ethanol (Fig. 1).

The study of physical-chemical properties of the obtained compounds was carried out using methods listed in the State Pharmacopoeia of Ukraine. The melting point was determined using capillary method on Stanford Research Systems Melting Point Apparatus 100 (SRS, USA). The structure of the compounds was confirmed with elemental analysis on Elemental Vario EL cube (Elementar Analysensysteme, Germany), IR spectra (4000-400 $\mathrm{cm}^{-1}$ ) were taken off the module ALPHA-T of Bruker ALPHA FT-IR spectrometer (Bruker optics, Germany). Chromato-mass-spectral studies were carried out on the instrument Agilent 1260 Series LC/MSD System, method of ionization - electrospray (ESI).

Amides of 2-[4-R-5-(theophyllin-7'-yl)-1,2,4-triazol-3ylthio]acetic acid. $A$. To $0.01 \mathrm{~mol}$ of ester of 2-[4-R-5-(theophyllin-7'-yl)-1,2,4-triazol-3-ylthio]acetic acid, $0.01 \mathrm{~mol}$ of amine and $35 \mathrm{ml}$ of propanol-1 are added, then heat for 3 hours. Water is added to the cooled reaction medium. The resulting precipitate is filtered off and recrystallized from 1,4-dioxane $(2-6,8-12,14-18)$ or ethanol $(1,7$, 13). White crystals, slightly soluble in water and alcohols (Table 1). B. A mixture of $0.01 \mathrm{~mol}$ of ester and $10 \mathrm{ml}$ of concentrated aqueous ammonia $(25 \%)$ is boiled for 12 hours. 
Table 1. Amides and hydrazides of 2-[4-R-5-(theophyllin-7'-yl)-1,2,4-triazol-3-ylthio] acetic acid

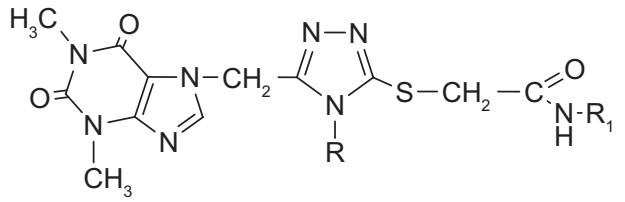

\begin{tabular}{|c|c|c|c|c|c|}
\hline Compound & $\mathrm{R}$ & $\mathrm{R}_{1}$ & M. p., ${ }^{\circ} \mathrm{C}$ & Molecular formula & Yield, \% \\
\hline 1 & $\mathrm{CH}_{3}$ & $\mathrm{H}$ & $150-151$ & $\mathrm{C}_{13} \mathrm{H}_{16} \mathrm{~N}_{8} \mathrm{O}_{3} \mathrm{~S}$ & 83 \\
\hline 2 & $\mathrm{CH}_{3}$ & $\mathrm{CH}_{3}$ & $187-189$ & $\mathrm{C}_{14} \mathrm{H}_{18} \mathrm{~N}_{8} \mathrm{O}_{3} \mathrm{~S}$ & 79 \\
\hline 3 & $\mathrm{CH}_{3}$ & $\mathrm{C}_{2} \mathrm{H}_{5}$ & $229-231$ & $\mathrm{C}_{15} \mathrm{H}_{20} \mathrm{~N}_{8} \mathrm{O}_{3} \mathrm{~S}$ & 72 \\
\hline 4 & $\mathrm{CH}_{3}$ & $\left(\mathrm{CH}_{2}\right)_{2} \mathrm{OH}$ & $211-213$ & $\mathrm{C}_{15} \mathrm{H}_{20} \mathrm{~N}_{8} \mathrm{O}_{4} \mathrm{~S}$ & 77 \\
\hline 5 & $\mathrm{CH}_{3}$ & $\left(\mathrm{C}_{2} \mathrm{H}_{4} \mathrm{OH}\right)_{2}$ & $280-285$ & $\mathrm{C}_{17} \mathrm{H}_{24} \mathrm{~N}_{8} \mathrm{O}_{5} \mathrm{~S}$ & 84 \\
\hline 6 & $\mathrm{CH}_{3}$ & $\mathrm{NH}_{2}$ & $245-247$ & $\mathrm{C}_{13} \mathrm{H}_{17} \mathrm{~N}_{9} \mathrm{O}_{3} \mathrm{~S}$ & 81 \\
\hline 7 & $\mathrm{C}_{2} \mathrm{H}_{5}$ & $\mathrm{H}$ & $237-240$ & $\mathrm{C}_{14} \mathrm{H}_{18} \mathrm{~N}_{8} \mathrm{O}_{3} \mathrm{~S}$ & 77 \\
\hline 8 & $\mathrm{C}_{2} \mathrm{H}_{5}$ & $\mathrm{CH}_{3}$ & $182-185$ & $\mathrm{C}_{15} \mathrm{H}_{20} \mathrm{~N}_{8} \mathrm{O}_{3} \mathrm{~S}$ & 85 \\
\hline 9 & $\mathrm{C}_{2} \mathrm{H}_{5}$ & $\mathrm{C}_{2} \mathrm{H}_{5}$ & $160-162$ & $\mathrm{C}_{16} \mathrm{H}_{22} \mathrm{~N}_{8} \mathrm{O}_{3} \mathrm{~S}$ & 84 \\
\hline 10 & $\mathrm{C}_{2} \mathrm{H}_{5}$ & $\left(\mathrm{CH}_{2}\right)_{2} \mathrm{OH}$ & $192-194$ & $\mathrm{C}_{16} \mathrm{H}_{22} \mathrm{~N}_{8} \mathrm{O}_{4} \mathrm{~S}$ & 72 \\
\hline 11 & $\mathrm{C}_{2} \mathrm{H}_{5}$ & $\left(\mathrm{C}_{2} \mathrm{H}_{4} \mathrm{OH}\right)_{2}$ & $209-211$ & $\mathrm{C}_{18} \mathrm{H}_{26} \mathrm{~N}_{8} \mathrm{O}_{5} \mathrm{~S}$ & 78 \\
\hline 12 & $\mathrm{C}_{2} \mathrm{H}_{5}$ & $\mathrm{NH}_{2}$ & $240-242$ & $\mathrm{C}_{14} \mathrm{H}_{19} \mathrm{~N}_{9} \mathrm{O}_{3} \mathrm{~S}$ & 71 \\
\hline 13 & $\mathrm{C}_{6} \mathrm{H}_{5}$ & $\mathrm{H}_{6}$ & $231-233$ & $\mathrm{C}_{18} \mathrm{H}_{18} \mathrm{~N}_{8} \mathrm{O}_{3} \mathrm{~S}$ & 69 \\
\hline 14 & $\mathrm{C}_{6} \mathrm{H}_{5}$ & $\mathrm{CH}_{3}$ & $176-177$ & $\mathrm{C}_{19} \mathrm{H}_{20} \mathrm{~N}_{8} \mathrm{O}_{3} \mathrm{~S}$ & 58 \\
\hline 15 & $\mathrm{C}_{6} \mathrm{H}_{5}$ & $\mathrm{C}_{2} \mathrm{H}_{5}$ & $194-196$ & $\mathrm{C}_{20} \mathrm{H}_{22} \mathrm{~N}_{8} \mathrm{O}_{3} \mathrm{~S}$ & 65 \\
\hline 16 & $\mathrm{C}_{6} \mathrm{H}_{5}$ & $\left(\mathrm{CH}_{2}\right)_{2} \mathrm{OH}$ & $234-235$ & $\mathrm{C}_{20} \mathrm{H}_{22} \mathrm{~N}_{8} \mathrm{O}_{4} \mathrm{~S}$ & 84 \\
\hline 17 & $\mathrm{C}_{6} \mathrm{H}_{5}$ & $\left(\mathrm{C}_{2} \mathrm{H}_{4} \mathrm{OH}\right)_{2}$ & $210-212$ & $\mathrm{C}_{22} \mathrm{H}_{26} \mathrm{~N}_{8} \mathrm{O}_{5} \mathrm{~S}$ & 75 \\
\hline
\end{tabular}<smiles>[R]n1c(S)nnc1Cn1cnc2c1c(=O)n(C)c(=O)n2C</smiles><smiles>[Y16]n1c(Cn2cnc3c2c(=O)n(C)c(=O)n3C)nnc1SCC(N)=O</smiles>

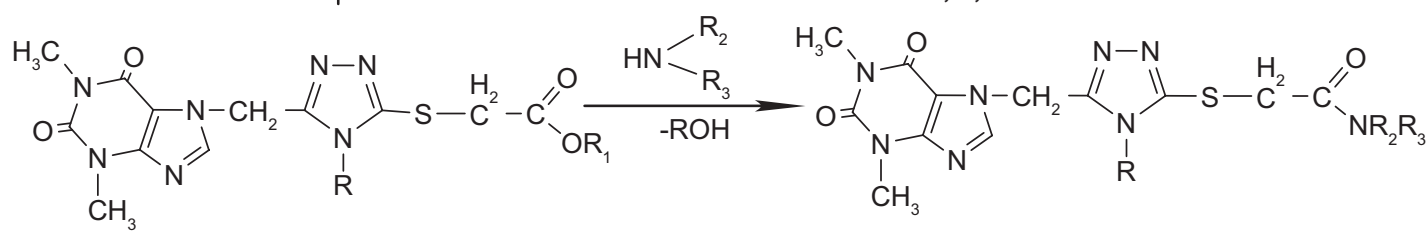

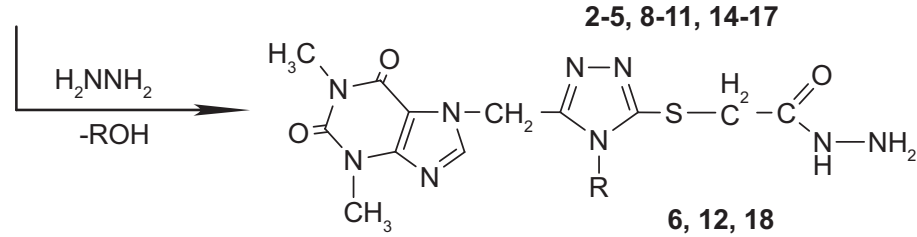

Fig. 1. The scheme of the synthesis of amides and hydrazides of 2-[4-R-5-(theophylline-7'-yl)-1,2,4-triazole-3-ylthio]acetic acid. 
The resulting solution is evaporated; the residue is crystallized from ethanol. White crystals are insoluble in water and alcohols. Washed with ethanol and dried. White crystalline substances, practically insoluble in water and slightly soluble in alcohols.

\section{Results and their discussion}

The presence of the amide group in the IR-spectrum of the obtained compounds was confirmed by the presence of characteristic absorption bands in the region of 3132$3370 \mathrm{~cm}^{-1}\left(\mathrm{CONH}_{2}\right)$ and in the region $1630-1675 \mathrm{~cm}^{-1}$ $\left(\mathrm{CONH}_{2}\right)$. The absorption band of the secondary amino group was observed in the range of $3165-3200 \mathrm{~cm}^{-1}$. The IR-spectrum of compounds 4, 5, 11, 12, 17, 18 in addition to the above has an additional absorption band within 950-890 $\mathrm{cm}^{-1}$, indicating the presence of $\mathrm{OH}$-groups.

In the NMR ${ }^{1} \mathrm{H}$ synthesized compounds, signals of protons with chemical displacements are present, which confirm the structure of the resulting compounds. Signals of protons of methylene groups (3.75-3.85 ppm), aromatic prototype multiplets - for compounds 13-18 (7.25-8.16 ppm). In addition, proton of amide $\mathrm{NH}$-group (7.65-7.93 ppm), a proton of the hydroxyl group (2.09-4.71 ppm). Intense signals of protons of methyl groups of the xanthine fragment are recorded in intervals at 3.15-3.30 ppm, and at 3.50-3.60 ppm. The signal of the methyl proton of the indicated fragment is registered in the form of a singlet in the range of 8.30$8.43 \mathrm{ppm}$. The protons of the thiomethylene moiety resonate at $3.88 \mathrm{ppm}$ in the form of a singlet. In compound 13, the magnetic properties of the protons of the phenyl substituent and the amide group were so close that their resonance frequencies practically coincided: in spectra for protons signals of these two groups one single multiplier with a total intensity of $7 \mathrm{H}$ can be observed at 6.65-7.75 ppm.

In the mass spectrum, there is a peak of the molecular ion and peaks of fragment ions, which confirm this structure.

\section{Conclusions}

A universal method for the preparation of 2-[4-R-5(theophylline-7'-yl)-1,2,4-triazol-3-ylthio]acetic acid amides and hydrazides was developed. It was established that while the interaction of the starting thiol with 2-chloroacetamide the product yields of the reaction are greater than in the reaction of the corresponding ester with ammonia.

\section{References}

[1] Anshul, C., \& Amanpreet, K. (2014) Extensive study on microwave assisted synthesis of monocyclic heterocyclic compounds. International journal of universal pharmacy and bio sciences, 3(1), 133-135.

[2] Bechara, W. S., Khazhieva, I. S., Rodriguez, E., Charette, A. B. (2015) Synthesis of 3,4,5-trisubstituted 1,2,4-triazoles via the addition of hydrazides to activated secondary amides. Org. Lett., 17(5), 1184-1187. doi: 10.1021/acs. orglett.5b00128.

[3] Chenglu, Zhang, Huan, Xi, Yuting, Sha, Xiaona, Sun, Chuanyin, Li, Jing, Wang, \& Yizheng, Li. (2017) Synthesis and bioactivity of novel bis-heterocyclic amide modified sulfide derivatives. Chinese Journal of Applied Chemistry, 34(3), 308-315.

[4] El-Wahab, H., Hamdy, A. -R.M., Gamal-Eldin, S. A., \& El-Gendy, M. A. (2011) Synthesis, biological evaluation and molecular modeling study of substituted 1,2,4-triazole-3-acetic acid derivatives. Der Pharma Chemica, 3(6), 540-552.

[5] Franklim, T. N., Freire-de-Lima, L., Diniz, J., Previato, J., Castro, R., Mendonça-Previato, L., \& Lima, M. (2013) Synthesis and trypanocidal evaluation of novel 1,2,4-triazoles-3-thiones derived from natural piperine. Molecules, 18, 6366-6382. doi: 10.3390/molecules 18066366.

[6] Pachuta-Stec, A., Kosikowska, U., Chodkowska, A., Pitucha, M., Malm, \& A., Jagiełło-Wójtowicz, E. (2012) Biological activity of novel $N$-substituted amides of endo-3-(3-methylthio-1,2,4-triazol-5-yl)bicyclo[2.2.1] hept-5-ene-2-carboxylic acid and $\mathrm{N}$-substituted amides of 1-(5-methylthio-1,2,4-triazol-3-yl)cyclohexane-2-carboxylic acids. Z. Naturforsch, 67, 123-128. doi: 10.5560/ZNC. $2012.67 \mathrm{c} 0123$.

[7] Ruping, T., Linhong, J., Mou, C., Yin, J., Bai, S., Hu, D., et al. (2015) Synthesis, antifungal and antibacterial activity for novel amide derivatives containing a triazole moiety. Chemistry Central Journal, 7, 30. doi: 10.1186/1752153X-7-30.

[8] Sydorenko, L. V., Ukrainets, I. V., \& Alieksieieva, T. B. (2009) Syntez ta vyvchenia antymikobakterialnoi aktyvnosti monoftorbenzylamid 1-R-4-hidroksy-2-okso-1,2-dyhidrokhinolin-3-karbonovykh kyslot [The synthesis and study of the antimycobacterial activity of monofluorobenzylamides of 1-R-4-hydroxy-2-oxo-1,2-dihydroquinoline-3-carboxylic acids]. Visnyk farmatsii, 2(58), 12-15. [in Ukrainian].

[9] Ukrainets, I. V., Sydorenko, L. V., Horokhova, O. V., et al. (2004) Syntez, budova ta protytuberkulozni vlastyvosti N-R-amidiv1-tsyklopropil-2-okso-4-hidroksy-1,2,5,6,7,8-heksahidrokhinolin-3-karbonovi kysloty [Synthesis, structure and anti-tuberculosis properties of $\mathrm{N}$-R-amides 1-cyclopropyl-2-oxo-4-hydroxy-1,2,5,6,7,8-hexahydroquinoline-3-carboxylic acid]. Visnyk farmatsii, 2(38), 7-12. [in Ukrainian].

[10] Vikas, G. R., Kiran, G., \& Vinayak, D. (2014) Synthesis, characterization and study of some $N$-substituted aryl-2-( $\{4-[(-$ substituted Aryl carbamoyl)methyl]-5-(pyridin-4-yl)- $4 \mathrm{H}$ 1,2,4-triazol-3-yl sulfanyl)acetamide. Iranian Journal of Pharmaceutical Sciences, 10(2), 21-34.

\section{Information about author:}

Gotsulya A. S., Ph.D., Associate Professor, the Department of Toxicology and Inorganic Chemistry, Zaporizhzhia State Medical University, Ukraine.

\section{Відомості про автора:}

Гоцуля А. С., канд. фарм. наук, доцент каф. токсикологічної та неорганічної хімії, Запорізький державний медичний університет, Україна. 


\section{Сведения об авторе:}

Гоцуля А. С., канд. фарм. наук, доцент каф. токсикологической и неорганической химии, Запорожский государственный медицинский университет, Украина.

E-mail: andrey.goculya@gmail.com

Конфмікт інтересів: відсутній.

Conflicts of Interest: author has no conflict of interest to declare.

Надійшло до редакції / Received: 25.09.2017

Після доопрацювання / Revised: 28.09.2017

Прийнято до друку / Accepted: 02.10.2017 